\title{
Passive remediation of acid mine drainage using cryptocrystalline magnesite: A batch experimental and geochemical modelling approach
}

\author{
Vhahangwele Masindi ${ }^{1,3 *}$, Mugera Wilson Gitari ${ }^{1}$, Hlanganani Tutu ${ }^{2}$ and Marinda De Beer ${ }^{4}$ \\ 'Environmental Remediation and Water Pollution Chemistry Research Group, Department of Ecology and Resources Management, School of \\ Environmental Science, University of Venda, P/bag X5050, Thohoyandou, 0950, South Africa \\ ${ }^{2}$ Molecular Sciences Institute, School of Chemistry, University of the Witwatersrand, P/Bag X4, WITS, 2050, Johannesburg, South Africa \\ ${ }^{3}$ CSIR (Council of Scientific and Industrial Research), Built Environment, Building Science and Technology (BST), P.O Box 395, Pretoria, 0001, \\ South Africa \\ ${ }^{4}$ DST/CSIR National Centre for Nano-Structured Materials, Council for Scientific and Industrial Research, P.O Box 395, Pretoria, 0001, \\ South Africa
}

\begin{abstract}
Acid mine drainage is generated when mining activities expose sulphidic rock to water and oxygen leading to generation of sulphuric acid effluents rich in $\mathrm{Fe}, \mathrm{Al}, \mathrm{SO}_{4}$ and $\mathrm{Mn}$ with minor concentrations of $\mathrm{Zn}, \mathrm{Cu}, \mathrm{Mg}, \mathrm{Ca}, \mathrm{Pb}$ depending on the geology of the rock hosting the minerals. These effluents must be collected and treated before release into surface water bodies. Mining companies are in constant search for cheaper, effective and efficient mine water treatment technologies. This study assessed the potential of applying magnesite as an initial remediation step in an integrated acid mine drainage (AMD) management system. Neutralization and metal attenuation was evaluated using batch laboratory experiments and simulations using geochemical modelling. Contact of AMD with cryptocrystalline magnesite for $60 \mathrm{~min}$ at $1 \mathrm{~g}: 100 \mathrm{~m} \ell$ $\mathrm{S} / \mathrm{L}$ ratio led to an increase in $\mathrm{pH}$, and a significant increase in metals attenuation. Sulphate concentration was reduced to $\approx 1910 \mathrm{mg} / \ell$. PH redox equilibrium (in C language) (PHREEQC) geochemical modelling results showed that metals precipitated out of solution to form complex mineral phases of oxy-hydroxysulphates, hydroxides, gypsum and dolomite. The results of this study showed that magnesite has potential to neutralize AMD, leading to the reduction of sulphate and precipitation of metals.
\end{abstract}

Keywords: acid mine drainage, cryptocrystalline magnesite, toxic metals, geochemical modelling, water treatment

\section{INTRODUCTION}

The aftermath of gold and coal mining has triggered serious environmental problems that need urgent attention prior to degradation of terrestrial and aquatic ecosystems and their ability to foster life (Jooste et al., 1999; Luís et al., 2009; Raymond et al., 2009; Equeenuddin et al., 2010). Mining of the aforementioned minerals exposes sulphidebearing minerals to oxidising conditions. During rainfall and underground working, sulphide minerals react with water and oxygen leading to the formation of highly acidic mine effluent known as acid mine drainage (AMD). The acidity in AMD promotes the leaching of heavy metals from the surrounding geology (Johnson et al., 2005; Sheoran et al., 2006; Cheng et al., 2009; Simate et al., 2014; Amos et al., 2015; Delkash et al., 2015). The equation below shows the formation of acid mine drainage using pyrite as an example (Simate et al., 2014):

$$
4 \mathrm{FeS}_{2}+15 \mathrm{O}_{2}+14 \mathrm{H}_{2} \mathrm{O} \stackrel{\text { bacteria }}{\longrightarrow} 4 \mathrm{Fe}(\mathrm{OH})_{3}+8 \mathrm{SO}_{4}^{2-}+16 \mathrm{H}^{+}
$$

\footnotetext{
* To whom all correspondence should be addressed. ฮ + 2712841 4107, E-mail: VMasindi@csir.co.za; masindivhahangwele@gmail.com Received: 26 November 2014; accepted in revised form 15 September 2015
}

In the Witwatersrand gold ores of South Africa, for instance, up to 70 minerals have been identified, including gold, pyrite, uraninite $\left(\mathrm{U}_{3} \mathrm{O}_{8}\right)$, sphalerite $(\mathrm{ZnS})$, galena $(\mathrm{PbS})$ and various silicates among others (Tutu et al., 2008, 2009). Numerous technologies have been developed for remediation of acid mine drainage (Gitari et al., 2008; Delkash et al., 2015; Lakovleva et al., 2015). The commonly used technologies include ion exchange (Buzzi et al., 2013), reverse osmosis (Johnson et al., 2005), adsorption (Gitari, 2014; Lakovleva et al., 2015), biosorption (Sheoran et al., 2006) and precipitation (Bologo et al., 2012; Maree et al., 2013). However, generation of secondary sludge, toxicity, high operation costs, poor efficiency and demand for large expanses of land limit the application of the majority of developed technologies (Johnson et al., 2005; Kalin et al., 2006; Sheoran et al., 2006, Simate et al., 2014).

The Witwatersrand Basin produces approximately 340 Ml/day of mine water (Bologo et al., 2012) and this has been reported to impair the quality of water downstream (Jooste et al., 1999). Treatment of large volumes of mine effluents requires a very effective and efficient technology. In South Africa, limestone has been widely used as the main chemical agent for neutralization and removal of metals in acid mine waters (Maree et al., 1994, 2004, 2013). However, the use of limestone has the limitation of precipitating toxic metals with gypsum and raising $\mathrm{pH}>7$ (Maree et al., 1993). 
The present study was designed to develop a novel technology of using cryptocrystalline magnesite for remediation of acid mine drainage (AMD). Moreover, large deposits of cryptocrystalline magnesite in the Limpopo Province of South Africa (Masindi et al., 2014, 2014, 2015), and its low cost, makes it an attractive option for AMD remediation. This study explored, for the first time, changes in solution chemistry and elemental speciation during the reaction of magnesite and AMD by simulating these processes using the PHREEQC geochemical modelling code. The quality of product will be compared to Department of Water and Sanitation (formerly the Department of Water Affairs and Forestry (DWAF)) water quality guidelines (DWAF 1996).

\section{MATERIALS AND METHODS}

\section{Sampling}

Raw magnesite rock was collected from the Folovhodwe Magnesite Mine in Limpopo Province, South Africa (22 $35^{\prime} 47.0^{\prime \prime} \mathrm{S}$ and $30^{\circ} 25^{\prime} 33^{\prime \prime} \mathrm{E}$ ), prior to any processing at the mine. Field AMD samples were collected from a decant point in a disused mine shaft in Krugersdorp, Gauteng Province, South Africa.

\section{Simulated acid mine drainage}

Synthetic acid mine drainage (SAMD) was used for the batch optimization experiments as real acid drainage is unstable over long periods of time due to oxidation and hydrolysis which changes its chemistry. A simplified solution containing the major ions found in acid mine waters was prepared with reference to the study by Tutu et al. (2008). Synthetic AMD solution was simulated by dissolving the following quantities of salts $\left(7.48 \mathrm{~g} \mathrm{Fe}_{2}\left(\mathrm{SO}_{4}\right)_{3} \cdot \mathrm{H}_{2} \mathrm{O}, 2.46 \mathrm{~g} \mathrm{Al}_{2}\left(\mathrm{SO}_{4}\right)_{3} \cdot 18 \mathrm{H}_{2} \mathrm{O}\right.$, and $0.48 \mathrm{~g} \mathrm{MnCl}_{2}$ from Merck, 99\% purity) in $1000 \mathrm{ml}$ of Merck Millipore Milli-Q $18.2 \mathrm{M} \Omega \cdot \mathrm{cm}$ water to give a solution of $2000 \mathrm{mg} / \ell \mathrm{Fe}^{3+}, 200 \mathrm{mg} / \ell \mathrm{Al}^{3+}$ and $200 \mathrm{mg} / \ell \mathrm{Mn}^{2+} .5 \mathrm{~m} \ell$ of $0.05 \mathrm{M} \mathrm{H}_{2} \mathrm{SO}_{4}$ was added to make up the $\mathrm{SO}_{4}{ }^{2-}$ concentration to $6000 \mathrm{mg} / \ell$ and ensure $\mathrm{pH}$ below 3 , in order to prevent immediate precipitation of ferric hydroxide. The SAMD was prepared with deionized water. The salts were dissolved in a $1000 \mathrm{~m} \ell$ volumetric flask.

\section{Preparation of magnesite}

Magnesite samples were milled to a fine powder for $15 \mathrm{~min}$ at 800 r/min using a Retsch RS 200 vibratory ball mill (PM 100, Retsch-Allee 1 - 5, Haan, Germany) and passed through $<32 \mu \mathrm{m}$ particle size sieve. The samples were kept in a zip-lock plastic bag until utilization for AMD treatment.

\section{Characterization of aqueous samples}

Total dissolved solids (TDS), $\mathrm{pH}$ and electrical conductivity (EC) were monitored using CRISON MM40 portable $\mathrm{pH} / \mathrm{EC} /$ TDS/temperature multimeter probe. Aqueous samples were analysed using ICP-MS (7500ce, Agilent, Alpharetta, GA, USA) for metal cations and sulphate was analysed using IC (850 professional IC Metrohm, Herisau, Switzerland). The accuracy of the analysis was monitored by analysis of National Institute of Standards and Technology (NIST) water standards. Three replicate measurements were made on each sample and results are reported as the mean of the three samples.

\section{Elemental composition of X-ray fluorescence}

For elemental analysis by XRF, the samples were dried at $100^{\circ} \mathrm{C}$ and roasted at $1000^{\circ} \mathrm{C}$ to determine loss on ignition (LOI). $1 \mathrm{~g}$ sample of magnesite was then mixed with $6 \mathrm{~g}$ lithium-tetraborate flux and fused at $1050^{\circ} \mathrm{C}$ to make a stable fused glass bead. For trace element analysis, the samples were mixed with a PVA binder and pressed into a pellet using a $10 \mathrm{t}$ press. Major and minor elemental analysis of the prepared powdered magnesite samples was done by a PAN analytical Axios X-ray fluorescence spectrometer equipped with a $4 \mathrm{~kW}$ Rh tube.

\section{Batch experiments: optimization of inorganic contaminant removal conditions}

Optimization experiments were done in batch experimental procedures. Parameters optimized included magnesite dosage and particle size. To evaluate effects of magnesite dosage on reaction kinetics, the dosage was varied from $0.1-8 \mathrm{~g}$ (2000 mg/ $/ \ell \mathrm{Fe}^{3+}, 200 \mathrm{mg} / \ell \mathrm{Al}^{3+}, 100 \mathrm{mg} / \ell \mathrm{Mn}^{2+}, 6000 \mathrm{mg} / \ell$ $\mathrm{SO}_{4}^{2-}, 250 \mathrm{r} / \mathrm{min}, 60 \mathrm{~min}$ of reaction and $26^{\circ} \mathrm{C}$ ). To study the effects of particle size, aliquots of $100 \mathrm{m \ell}$ each and containing $2000 \mathrm{mg} / \ell \mathrm{Fe}^{3+}, 200 \mathrm{mg} / \ell \mathrm{Al}^{3+}, 100 \mathrm{mg} / \ell \mathrm{Mn}^{2+}$ and $6000 \mathrm{mg} / \ell \mathrm{SO}_{4}{ }^{2-}$ were pipetted into $250 \mathrm{~m} \ell$ flasks and $1 \mathrm{~g}$ of varying particle sizes (ranging from 1-2 $000 \mu \mathrm{m}$ ) of magnesite added into each flask. Other conditions include: 60 min retention time, ambient room temperature, $250 \mathrm{r} / \mathrm{min}$ equilibration speed, $100 \mathrm{~m} \ell$ and $\mathrm{pH}<3$. Optimized conditions were used for testing the feedstock capacity to neutralize and attenuate from field mine effluents.

\section{Treatment of field AMD at optimized conditions}

Field AMD samples were treated at established optimized conditions in order to assess the effectiveness of magnesite. EC, $\mathrm{pH}$ and TDS were measured using CRISON MM40 multimeter probe. The resultant solid residue after treatment of raw AMD was characterized in an attempt to gain insights into the fate of chemical species.

\section{Geochemical modelling}

To complement chemical solution and physicochemical characterization results, the ion association model PHREEQC was used to calculate ion activities and saturation indices of mineral phases based on the $\mathrm{pH}$ and solution concentrations of major ions in supernatants that were analysed after the optimized conditions. Mineral phases that were likely to form during treatment of AMD were predicted using the PHREEQC geochemical modelling code using the WATEQ4F database (Parkhurst and Appelo, 1999). Species which are more likely to precipitate were determined using the saturation index (SI). SI $<1=$ under saturated solution, $\mathrm{SI}=1=$ saturated solution and SI $>1=$ aupersaturated solution.

\section{RESULTS AND DISCUSSION}

\section{Elemental composition by X-ray fluorescence}

The elemental composition of magnesite before and after interaction with raw AMD is shown in Table 1.

Magnesite was observed to contain $\mathrm{Mg}$ as the major 
component. There were impurities of $\mathrm{Si}$ and $\mathrm{Ca}$ which were observed to be present. After the reaction, $\mathrm{Al}, \mathrm{Fe}, \mathrm{Mn}, \mathrm{Zn}$, $\mathrm{Cu}, \mathrm{Co}, \mathrm{Nb}, \mathrm{Ni}, \mathrm{Pb}, \mathrm{SO}_{3}, \mathrm{Sr}, \mathrm{Y}, \mathrm{Zr}, \mathrm{Cr}$ and $\mathrm{Ba}$ were found to be present in the resultant solid residues. The results obtained for the raw magnesite corroborated results from the study by Nasedkin et al. (2001). In their study, they reported that cryptocrystalline magnesite is characterized by $90-92$ wt $\%$ of $\mathrm{MgO}$ and very few other impurities. The levels of $\mathrm{Al}, \mathrm{Fe}$, $\mathrm{Mg}, \mathrm{Ca}, \mathrm{Mn}$ and $\mathrm{S}$ were observed to increase in the resultant solid residues indicating formation of new phases that include those mineral phases. This could be explained by a decrease in their levels in the product water (Table 3). The presence of $\mathrm{Mn}, \mathrm{Fe}, \mathrm{Al}, \mathrm{Ca}, \mathrm{Mg}, \mathrm{C}$ and $\mathrm{O}$ suggest minerals such as $\mathrm{Mn}, \mathrm{Fe}$, Al oxide, metals hydroxides, $\mathrm{Mn}$ and Fe carbonate, gypsum, $\mathrm{Al}$ and Fe oxyhydrosulphates. The PHREEQC simulation also predicted precipitation of mineral phases bearing these metal species.

\section{TABLE 1}

Elemental composition of magnesite before and after treatment of AMD

\begin{tabular}{|c|c|c|}
\hline Sample & Magnesite & AMD-magnesite \\
\hline \multicolumn{3}{|c|}{ Major elements (wt\%) } \\
\hline $\mathrm{SiO}_{2}$ & 6.1 & 5.25 \\
\hline $\mathrm{Al}_{2} \mathrm{O} 3$ & 0.7 & 0.60 \\
\hline $\mathrm{Fe}_{2} \mathrm{O}_{3}(\mathrm{t})$ & 0.55 & 2.45 \\
\hline $\mathrm{MnO}$ & 0.01 & 0.45 \\
\hline $\mathrm{MgO}$ & 82.1 & 60 \\
\hline $\mathrm{CaO}$ & 2.4 & 4.90 \\
\hline $\mathrm{Na}_{2} \mathrm{O}$ & 0.1 & 0.10 \\
\hline $\mathrm{K}_{2} \mathrm{O}$ & 0.1 & 0.05 \\
\hline $\mathrm{SO}_{3}$ & 0.2 & 10 \\
\hline LOI & 7.3 & 19.05 \\
\hline Total & 99.6 & 100 \\
\hline $\mathrm{H}_{2} \mathrm{O}$ & 1.60 & 2 \\
\hline \multicolumn{3}{|c|}{ Trace elements $\left(\mathrm{mg} \cdot \ell^{-1}\right)$} \\
\hline As & $<4$ & 9 \\
\hline $\mathrm{Ba}$ & $<5$ & 9 \\
\hline $\mathrm{Br}$ & 2.5 & $<2$ \\
\hline Co & $<1$ & 6.0 \\
\hline $\mathrm{Cr}$ & 3.5 & 15 \\
\hline $\mathrm{Cu}$ & 6.0 & 11 \\
\hline $\mathrm{Ga}$ & 1.1 & 1.9 \\
\hline $\mathrm{Hf}$ & 8.5 & 10 \\
\hline $\mathrm{Nb}$ & 158 & 225 \\
\hline $\mathrm{Ni}$ & 11 & 137 \\
\hline $\mathrm{Pb}$ & 4 & 21 \\
\hline $\mathrm{Se}$ & 11 & 21 \\
\hline $\mathrm{Sr}$ & 5.5 & 84 \\
\hline $\mathrm{Ta}$ & 4.0 & 22 \\
\hline $\mathrm{Y}$ & 2 & 32 \\
\hline $\mathrm{Zn}$ & 1 & 39 \\
\hline $\mathrm{Zr}$ & $<2$ & 5.5 \\
\hline
\end{tabular}

http://dx.doi.org/10.4314/wsa.v41i5.10

Available on website http://www.wrc.org.za

ISSN 1816-7950 (On-line) = Water SA Vol. 41 No. 5 October 2015

Published under a Creative Commons Attribution Licence

\section{Optimisation results}

\section{Effect of magnesite dosage}

The results for neutralization and metal removal efficiency as a function of magnesite dosage are presented in Fig. 1.

The experimental results showed that there was an increase in $\mathrm{pH}$ with an increase in dosage. An increase in $\mathrm{pH}$ would be expected since an increase in dosage results in an increase in alkalinity and precipitation of metals. An increase in alkalinity was also verified by modelling. Simulations showed an increase in alkalinity from $2 \times 10^{-02}$ for $0.1 \mathrm{~g}$ of magnesite to $3 \times 10^{-01} \mathrm{eq} /$ $\mathrm{kg}$ for $8 \mathrm{~g}$ magnesite. Modelling predicted that as $\mathrm{pH}$ increases, $\mathrm{Fe}^{3+}$ species precipitate at $\mathrm{pH}>6, \mathrm{Al}^{3+}$ bearing species at $\mathrm{pH}>$ $6, \mathrm{Fe}^{2+}$ species at $\mathrm{pH}>8$ and $\mathrm{Mn}^{2+}$ bearing species at $\mathrm{pH}>10$ (Table 1). The trend showed a lower per cent removal of sulphate compared to that for metals. This could be attributed to the formation of $\mathrm{MgSO}_{4}$ and, partly, $\mathrm{CaSO}_{4}$, which remains in solution until saturation and only precipitates at elevated dosages. This is substantiated by the higher solubility of $\mathrm{MgSO}$ $\left(K_{\mathrm{sp}}=5.9 \times 10^{-3}\right)$ compared to that of $\mathrm{CaSO}_{4}\left(K_{\mathrm{sp}}=4.93 \times 10^{-5}\right)$, suggesting that more magnesite should be dissolved so as to precipitate out $\mathrm{MgSO}_{4}$ and $\mathrm{CaSO}_{4}$ (Langmuir et al., 1997). The speciation of $\mathrm{Ca}$ and $\mathrm{Mg}$ was also assessed using geochemical modelling and the results showed that calcium existed as $\mathrm{CaCO}_{3}, \mathrm{Ca}^{2+}, \mathrm{CaOH}^{+}, \mathrm{CaSO}_{4}, \mathrm{CaHCO}_{3}^{-}, \mathrm{CaHSO}_{4}^{+}$and magnesium as $\mathrm{MgOH}^{+}, \mathrm{MgCO}_{3}, \mathrm{Mg}^{2+}, \mathrm{MgSO}_{4}, \mathrm{MgHCO}_{3}^{+}$. Metal complexes were predicted to precipitate as hydroxide and oxyhydroxides, and to co-precipitate as oxyhydroxysulphates. These results were similar to those obtained by Bologo et al. (2012). From the dosage experiments, it was concluded that optimum neutralization and metal attenuation conditions were $60 \mathrm{~min}$ of contact time and $1 \mathrm{~g}$ of magnesite dosage (at 1:100 S/L ratios). The results in the following sections are based on these optimal conditions.

\section{Effect of magnesite particle size}

The results for neutralization and metal removal efficiency of magnesite as a function of particle size are presented in Fig. 2.

Particle size is an important parameter in neutralization and metal attenuation processes. The smaller the particle size,

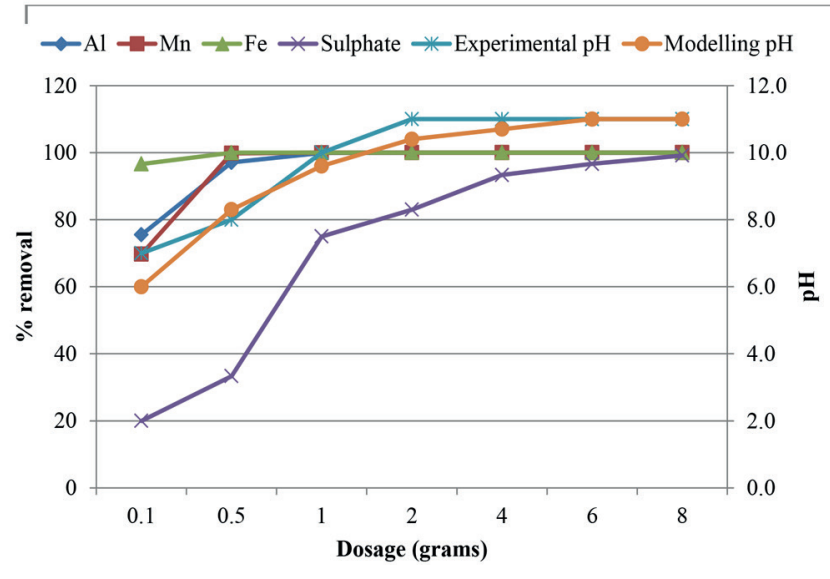

Figure 1

Variation of $\mathrm{pH}, \mathrm{Al}, \mathrm{Fe}, \mathrm{Mn}$ and sulphate concentration with adsorbent dosage (conditions: $2000 \mathrm{mg} / \mathrm{l} \mathrm{Fe}{ }^{3+}, 200 \mathrm{mg} / \mathrm{l} \mathrm{Al}^{3+}, 100 \mathrm{mg} / \mathrm{l} \mathrm{Mn}^{2+}$, $6000 \mathrm{mg} / \mathrm{l} \mathrm{SO}{ }_{4}^{2-}, 250 \mathrm{r} / \mathrm{min}$ shaking speed, $<32 \mu \mathrm{m}$ particle size, $100 \mathrm{ml}$, 60 min of shaking time and $26^{\circ} \mathrm{Croom}$ temperature) 
the larger the surface area provided for reaction and the faster the rate of neutralization and metal removal (Alloway, 1990). As shown in Fig. 2, the rate of neutralization and metal attenuation decreased with increasing particle size. At particle sizes $<125 \mu \mathrm{m}$ magnesite removed almost all contaminants and increased the $\mathrm{pH}$ of the aqueous solution. This study is comparative to those for calcium-based materials; for instance, with limestone, $\mathrm{pH}$ values of 6 and higher were achieved with particle sizes of $300 \mu \mathrm{m}$ and smaller (Maree et al., 2004) whereas particle sizes of $1000 \mu \mathrm{m}$ and smaller for magnesite were used to achieve $\mathrm{pH}>6$. Thus, the efficiency of magnesite is better than that of limestone.

\section{Simulation of mineral precipitation during treatment of synthetic AMD}

The results for the simulation of mineral precipitation at various $\mathrm{pH}$ values during treatment of raw AMD with magnesite are presented in Table 2.

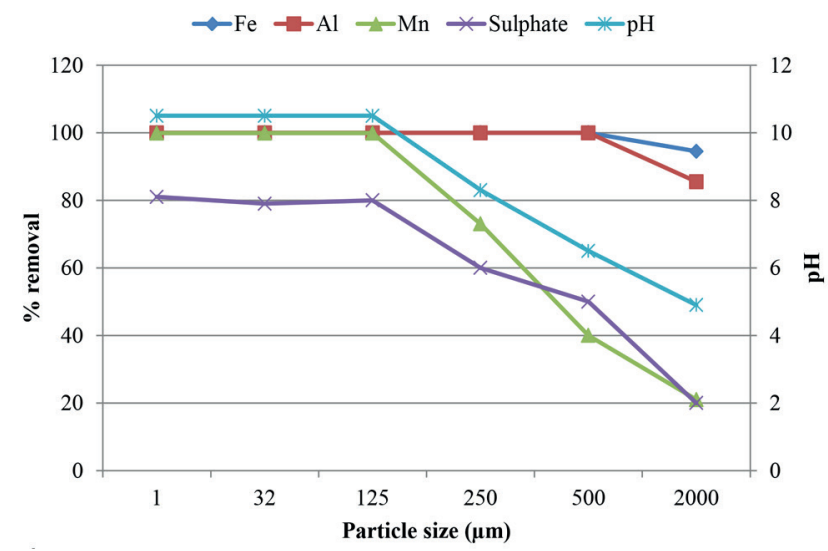

Figure 2

Variation of $\mathrm{Al}, \mathrm{Fe}, \mathrm{Mn}$ and $\mathrm{SO}_{4}{ }^{2-}$ with agitation time and variation of $\mathrm{pH}$ gradients with varying particle sizes (Conditions: $2000 \mathrm{mg} / \mathrm{l} \mathrm{Fe}{ }^{3+}$, $200 \mathrm{mg} / \mathrm{l} \mathrm{Al}{ }^{3+}, 100 \mathrm{mg} / \mathrm{l} \mathrm{Mn}{ }^{2+}, 6000 \mathrm{mg} / \mathrm{l} \mathrm{SO}{ }_{4}^{2-}, 60 \mathrm{~min}$ of shaking time, $250 \mathrm{r} / \mathrm{min}$ shaking speed, $1 \mathrm{~g}$ of dosage, $100 \mathrm{m \ell}, 60 \mathrm{~min}$ of shaking time and $26^{\circ} \mathrm{C}$ room temperature)

\begin{tabular}{|c|c|c|c|c|}
\hline \multicolumn{5}{|c|}{$\begin{array}{c}\text { TABLE } 2 \\
\begin{array}{c}\text { Minerals precipitating at various pH values during } \\
\text { treatment of raw AMD with magnesite }\end{array}\end{array}$} \\
\hline \multirow[t]{2}{*}{ Mineral phase } & \multicolumn{4}{|c|}{ pH and saturation indices (SI) } \\
\hline & 6 & 8 & 10 & 11 \\
\hline $\mathrm{Al}(\mathrm{OH})_{3}$ & 2.9 & 1.2 & -0.1 & -1.5 \\
\hline Boehmite (AlOOH) & 5 & 3.4 & 2.1 & 0.7 \\
\hline Basaluminite $\left[\mathrm{Al}_{4}(\mathrm{OH})_{10} \mathrm{SO}_{4}\right]$ & 17.4 & 6 & -1.4 & -10.2 \\
\hline Brucite $\left[(\mathrm{MgOH})_{2}\right]$ & -6.6 & -2 & 0.6 & 3.6 \\
\hline Diaspore $(\mathrm{AlOOH})$ & 6.8 & 5.1 & 3.1 & 2 \\
\hline Dolomite $\left[\mathrm{CaMg}\left(\mathrm{CO}_{3}\right)_{2}\right]$ & -1.3 & 4.9 & 6.9 & 8 \\
\hline Epsomite & -2 & -1.8 & -1.8 & -1.8 \\
\hline $\mathrm{Fe}(\mathrm{OH})_{3}$ & 3.7 & 4.6 & 3.2 & 3.1 \\
\hline Gibbsite $\left[\mathrm{Al}(\mathrm{OH})_{3}\right]$ & 5.5 & 3.7 & 1.8 & 0.8 \\
\hline Geothite $(\mathrm{FeOOH})$ & 9.7 & 10.5 & 9.1 & 9 \\
\hline Gypsum $\left(\mathrm{CaSO}_{4} \cdot \mathrm{H}_{2} \mathrm{O}\right)$ & -0.2 & 0.07 & 0.2 & 0.2 \\
\hline $\begin{array}{l}\text { Jarosite } \\
\mathrm{H}\left[\left(\mathrm{H}_{3} \mathrm{O}\right) \mathrm{Fe}_{3}\left(\mathrm{SO}_{4}\right)_{2}(\mathrm{OH})_{6}\right]\end{array}$ & 2.9 & -3.7 & -16 & -20 \\
\hline Jurbanite $\left(\mathrm{AlOHSO}_{4}\right)$ & 2.5 & -3.6 & -9.8 & -12.8 \\
\hline Manganite $(\mathrm{MnOOH})$ & -4.9 & -4 & -5.9 & -4.6 \\
\hline Pyrochroite $\left[\mathrm{Mn}(\mathrm{OH})_{2}\right]$ & -6.4 & -2 & 0.7 & 2.2 \\
\hline
\end{tabular}

Table 2 shows the minerals that would be expected to precipitate at various $\mathrm{pH}$ values during the treatment of synthetic $\mathrm{AMD}$ with magnesite. Most of the $\mathrm{Al}$ and Fe precipitated as hydroxides at $\mathrm{pH}>6$. Mn precipitated as magnesium hydroxide at $\mathrm{pH}>10$. Sulphate-bearing minerals precipitated at $\mathrm{pH}$ 6-8 (basaluminite), $\mathrm{pH}>8$ (gypsum), and pH 6 (jarosite and jurbanite). Generally, mineral phases were predicted to precipitate as metal hydroxides, hydroxysulphates and oxyhydroxysulphates. Epsomite $\left(\mathrm{MgSO}_{4}\right)$ was observed to be near precipitation but did not precipitate; this may be attributed to high solubility of epsomite $\left(K_{\mathrm{sp}}=5.9 \times 10^{-3}\right)$ (Bologo et al., 2012). However, it was observed that the sulphates were removed from solution with $\mathrm{Al}, \mathrm{Fe}$ and $\mathrm{Ca}$.

\section{Treatment of AMD at optimized conditions}

Most of the water quality parameters of the treated water were within those stipulated by the DWS water quality guidelines (Table 3) (DWAF, 1996).

As shown in Table 3, the mine effluent is constituted of high acidity $(\mathrm{pH}<2)$, TDS and EC. There is an elevated concentration of heavy metals, alkali and earth alkali metals. After treatment, only $\mathrm{Na}, \mathrm{Mg}, \mathrm{Ca}$ and sulphate remained with elevated concentrations in the treated water. The reduction of metal species could be described by the introduction of metals on the secondary residues (Table 1). Saturation indices from geochemical simulations suggested that these components were below their precipitation levels. The presence of $\mathrm{Mn}, \mathrm{Fe}, \mathrm{Al}$,

\begin{tabular}{|l|c|c|c|}
\hline \multicolumn{5}{|c|}{ TABLE 3} \\
Water quality parameters before and after treatment of \\
raw AMD with magnesite
\end{tabular}


$\mathrm{Ca}, \mathrm{Mg}, \mathrm{C}$ and $\mathrm{O}$ suggest minerals such as $\mathrm{Mn}, \mathrm{Fe}, \mathrm{Al}$ oxide, metals hydroxides, $\mathrm{Mn}$ and $\mathrm{Fe}$ carbonate, gypsum, $\mathrm{Al}$ and $\mathrm{Fe}$ oxyhydrosulphates. The simulations showed that in the feed water, $\mathrm{Fe}$ existed mainly as $\mathrm{Fe}^{2+}$ or $\mathrm{Fe}^{3+}$, while the rest of the metals, except for $\mathrm{Na}$ and $\mathrm{K}$, were in their divalent states at acidic $\mathrm{pH}$. A large proportion of Ca existed as soluble $\mathrm{CaSO}_{4}$. Cryptocrystalline removed the inorganic contaminants from mine effluent to a level that is suitable for irrigation purposes, especially in acidic soils, owing to its elevated $\mathrm{pH}$.

\section{CONCLUSION}

This study has shown that magnesite can be used to remediate AMD. Contact of AMD with magnesite led to an increase in $\mathrm{pH}$ and a notable reduction in metal and sulphate concentrations. Removal of $\mathrm{Al}, \mathrm{Mn}, \mathrm{Fe}$ and other metals was observed to be greatest at $60 \mathrm{~min}$ of agitation for a S:L ratio of $1 \mathrm{~g}: 100 \mathrm{m \ell}$. Under these conditions, the $\mathrm{pH}$ was observed to be greater than 10, an ideal regime for metals removal. Using geochemical modelling, it was shown that most metals, e.g., Fe, $\mathrm{Al}, \mathrm{Mn}$, $\mathrm{Ca}$ and $\mathrm{Mg}$ formed sulphate-bearing minerals. From modelling simulations, the formation of these was observed to follow a selective precipitation sequence with $\mathrm{Fe}^{3+}$ at $\mathrm{pH}>6, \mathrm{Al}^{3+}$ at $\mathrm{pH}>6, \mathrm{Fe}^{2+}$ at $\mathrm{pH}>8, \mathrm{Mn}^{2+}, \mathrm{Ca}^{2+}$ and $\mathrm{Mg}^{2+}$ at $\mathrm{pH}>10$. The presence of $\mathrm{Mn}, \mathrm{Fe}, \mathrm{Al}, \mathrm{Ca}, \mathrm{Mg}, \mathrm{C}$ and $\mathrm{O}$ suggest minerals such as $\mathrm{Mn}, \mathrm{Fe}, \mathrm{Al}$ oxide, metal hydroxides, $\mathrm{Mn}$ and $\mathrm{Fe}$ carbonate, gypsum, $\mathrm{Al}$ and $\mathrm{Fe}$ oxyhydrosulphates. This sequence implies that it would be possible to separate precipitates of metals, making this viable for instances where commercial value of the recovered metals is being pursued. Generally, the study has pointed to the efficiency of magnesite in neutralizing and attenuating metals from AMD and, possibly, metalliferous industrial effluents. While not all local water regulatory requirements could be obtained following treatment of raw AMD with magnesite, the resulting water quality was greatly improved, making further polishing easier.

\section{Schematic presentation of a proposed treatment plant}

The process flow of the proposed treatment plant for remediation of acid mine drainage using cryptocrystalline magnesite is shown in Fig. 3.

\section{ACKNOWLEDGEMENTS}

The authors wish to convey their sincere gratitude to Research and Innovation Directorate, Department of Ecology and Resource Management, School of Environmental Sciences, University of Venda, Council for Scientific and Industrial Research (CSIR), SASOL-INZALO, National Research Foundation (NRF) and Department of Science and Technology (DST) (DST/NRF) for funding this project. The authors would also like to convey their sincere gratitude to Rirhandzu Rikhotso for characterisation of our sample at DST/CSIR National Centre for Nano-Structured Materials.

\section{REFERENCES}

ALLOWAY BJ (1990) Heavy Metals in Soils. Chapman \& Hall, London. AMOS RT, BLOWES DW, BAILEY BL, SEGO DC, SMITH L and RITCHIE AIM (2015) Waste-rock hydrogeology and geochemistry. Appl. Geochem. 57 140-156.

BOLOGO V, MAREE JP and CARLSSON F (2012) Application of magnesium hydroxide and barium hydroxide for the removal of metals and sulphate from mine water. Water SA 38 (1) 23-28.

BUZZI DC, VIEGAS LS, RODRIGUES MAS, BERNARDES AM and TENÓRIO JAS (2013) Water recovery from acid mine drainage by electrodialysis. Miner. Eng. 40 82-89.

CHENG H, HU Y, LUO J, XU B and ZHAO J (2009) Geochemical processes controlling fate and transport of arsenic in acid mine drainage (AMD) and natural systems. J. Hazardous Mater. 165 (1-3) 13-26.

DELKASH M, EBRAZI BAKHSHAYESH B and KAZEMIAN H (2015) Using zeolitic adsorbents to cleanup special wastewater streams: A review. Micropor. Mesopor. Mater. 214 224-241.

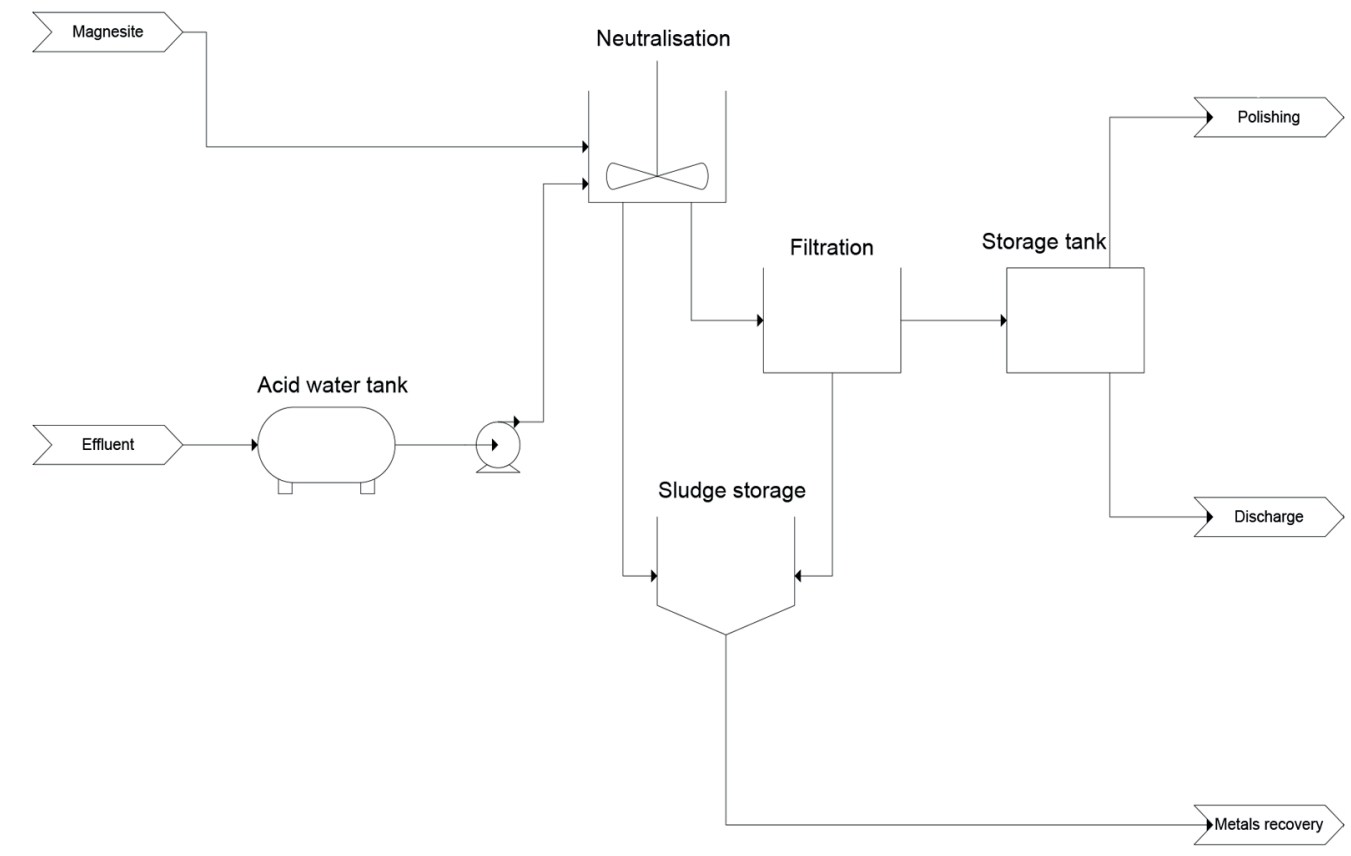

Figure 3

The process flow of the proposed treatment plant for remediation of acid mine drainage using cryptocrystalline magnesite 
DWAF (DEPARTMENT OF WATER AFFAIRS AND FORESTRY, PRETORIA) (1996) South African Water Quality Guidelines. Agricultural Use: Irrigation 4. DWAF, Pretoria.

EQUEENUDDIN SM, TRIPATHY S, SAHOO PK and PANIGRAHI MK (2010) Hydro-geochemical characteristics of acid mine drainage and water pollution at Makum Coalfield, India. J. Geochem. Explor. 105 (3) 75-82.

GITARI WM (2014) Attenuation of metal species in acidic solutions using bentonite clay: implications for acid mine drainage remediation. Toxicol. Environ. Chem. 96 (2) 201-217.

GITARI WM, PETRIK LF, ETCHEBERS O, KEY DL and OKUJENI C (2008) Utilization of fly ash for treatment of coal mines wastewater: Solubility controls on major inorganic contaminants. Fuel 87 (12) 2450-2462.

IAKOVLEVA E, MÄKILÄ E, SALONEN J, SITARZ M, WANG S and SILLANPÄÄ M (2015) Acid mine drainage (AMD) treatment: Neutralization and toxic elements removal with unmodified and modified limestone. Ecol. Eng. 81 30-40.

JOHNSON DB and HALLBERG KB (2005) Acid mine drainage remediation options: a review. Sci. Total Environ. 338 (1-2) 3-14.

JOOSTE S and THIRION C (1999) An ecological risk assessment for a South African acid mine drainage. Water Sci. Technol. 39 (10-11) 297-303.

KALIN M, FYSON A and WHEELER WN (2006) The chemistry of conventional and alternative treatment systems for the neutralization of acid mine drainage. Sci. Total Environ. 366 (2-3) 395-408.

LANGMUIR D, HALL P and DREVER J (1997) Environmental Geochemistry. Prentice Hall, New Jersey.

LUÍS AT, TEIXEIRA P, ALMEIDA SFP, ECTOR L, MATOS JX and FERREIRA DA SILVA EA (2009) Impact of acid mine drainage (AMD) on water quality, stream sediments and periphytic diatom communities in the surrounding streams of aljustrel mining area (Portugal). Water Air Soil Pollut. 200 (1-4) 147-167.

MAREE JP and DU PLESSIS P (1994) Neutralization of acid mine water with calcium carbonate. Water Sci. Technol. 29 (9) 285-296.

MAREE JP, MUJURU M, BOLOGO V, DANIELS N and MPHOLOANE D (2013) Neutralisation treatment of AMD at affordable cost. Water SA 39 (2) 245-250.

MAREE JP, STREYDOM WF, ADLEM CJL, DE BEER M, VAN TONDER GJ and VAN DIJK BJ (2004) Neutralization of acid mine water and sludge disposal. WRC Report No. 1057/1/04. Water Research Commission, Pretoria.

MASINDI V, GITARI MW, TUTU H and DE BEER M (2014) Application of magnesite-bentonite clay composite as an alternative technology for removal of arsenic from industrial effluents. Toxicolog. Environ. Chem. 96 (10) 1435-1451.

MASINDI V, GITARI MW, TUTU H and DE BEER M (2014) Neutralization and Attenuation of Metal Species in Acid Mine Drainage and Mine Leachates Using Magnesite: a Batch Experimental Approach. China University of Mining and Technology Press, Xuzhou. ISBN: 978-7-5646-2437-8.

MASINDI V, GITARI WM and NGULUBE T (2015) Kinetics and equilibrium studies for removal of fluoride from underground water using cryptocrystalline magnesite. J. Water Reuse Desalin. DOI: $10.2166 /$ wrd.2015.080.

NASEDKIN VV, KRUPENIN MT, SAFONOV YG, BOEVA NM, EFREMOVA SV and SHEVELEV AI (2001) The comparison of amorphous (cryptocrystalline) and crystalline magnesites. Mineralia Slovaca 33 567-574.

RAYMOND PA and OH N-H (2009) Long term changes of chemical weathering products in rivers heavily impacted from acid mine drainage: Insights on the impact of coal mining on regional and global carbon and sulfur budgets. Earth Planet. Sci. Lett. 284 (1-2) 50-56.

SHEORAN AS and SHEORAN V (2006) Heavy metal removal mechanism of acid mine drainage in wetlands: A critical review. Miner. Eng. 19 (2) 105-116.

SIMATE GS and NDLOVU S (2014) Acid mine drainage: Challenges and opportunities. J. Envirom. Chem. Eng. 2 (3) 1785-1803.

TUTU H, CUKROWSKA EM, MCCARTHY TS, HART R and CHIMUKA L (2009) Radioactive disequilibrium and geochemical modelling as evidence of uranium leaching from gold tailings dumps in the Witwatersrand Basin. Int. J. Environ. Anal. Chem. 89 (8-12) 687-703.

TUTU H, MCCARTHY TS and CUKROWSKA E (2008) The chemical characteristics of acid mine drainage with particular reference to sources, distribution and remediation: The Witwatersrand Basin, South Africa as a case study. Appl. Geochem. 23 (12) 3666-3684. 